\author{
Irina Wiebe, \\ Sales Controller, Automotive Department, \\ Sony Europe Limited, \\ Stuttgart, Germany \\ Viktor Oliinyk, \\ D.Sc., Associate Professor, Economic Cybernetics Department, \\ Sumy State University, \\ Sumy, Ukraine \\ Yulia Halynska, \\ Ph.D., Associate professor, Management Department, \\ Sumy State University, \\ Sumy, Ukraine
}

\title{
INNOVATIVE INSTRUMENT OF COLLABORATIVE ALLIANCE MANAGEMENT IN THE "STATE- REGION-ENTERPRISE" SYSTEM OF WITHDRAWAL OF THE RENT INCOME IN THE EXTRACTING INDUSTRY
}

\begin{abstract}
The state and prospects of the transformation of the rental policy of Ukraine are assessed and recommendations are proposed for improving rental relations through the introduction of innovative tools for regulating collaboration relations in the extracting industry. The paper suggests a mechanism for interaction of all members of the society in the formation and distribution of rental income from the extraction of natural resources by creating collaborative alliances between the state, extractive enterprises and regions. The conducted researches showed that collaborative alliances in nature management are the most acceptable and promising organizational form through which it is possible to coordinate the interests of all participants in the formation and distribution and redistribution of rental income. With the help of the questionnaire and the Delphi method from 2015 until 2017, research was conducted on the possibility of creating a collaborative alliance in environmental management in the "state-region-enterprise" system, certain shortcomings and advantages for all participants in the collaboration alliances (state-region-extractive enterprise) and identified socio-ecological and economic risks in the formation and functioning of collaborative alliances in the use of natural resources, which may not contribute to the harmonization of the interests of its participants. A risk management system has been established in the operation of collaborative alliances in the use of natural resources, which includes a subsystem for identification, measurement, support (control and monitoring of risks). The coefficient of concordance of $M$. Kendall and $B$. Smith was determined in assessing the probability of occurrence of negative consequences. In order to formalize the identified risks in the operation of collaborative alliances in nature management, a scientific and methodical approach to ranking social, economic and environmental risks in the creation of collaborative alliances using the Fuzzy Logic method was developed, based on considering the indicators of the stability of collaborative relationships in determining the most significant risks and their interdependencies. The ways of minimizing the occurrence of negative risks in the functioning of collaborative alliances in the system "state-region-enterprise" on the withdrawal of rent income in the fuel extraction industry are suggested. Studies have shown that today, in the context of the transformation of rental policy and socio-economic relations, state administration must form social values of society through environmental use and consumption of resources and to implement a saving policy regarding the extraction of natural resources in Ukraine. In the implementation of the collaborative alliance in the system "state-region-enterprise" interests of its parties can be considered regarding the redistribution of rental income from the extraction of natural resources, considering personal and social responsibility in the extraction of natural resources and the protection of the environment. At the same time, the risks identified and assessed correctly in the formation and functioning of the collaborative alliances in the "stateregion-enterprise" system will help to optimize the distribution of natural resource rent from the extraction of natural resources in order to compensate, hedge and save them for future generations. Thus, it can be concluded that the
\end{abstract}


I. Wiebe, V. Oliinyk, Y. Halynska. Innovative Instrument of Collaborative Alliance Management in the "State-RegionEnterprise" System of Withdrawal of the Rent Income in the Extracting Industry

collaboration between the state and extractive enterprises and local communities is not only possible, but also necessary for the effective functioning of the state's ecological and economic system. At the same time, fuel-extracting companies can operate under coopetition conditions, creating additional incentives for the development of enterprises, minimizing risks and generating innovative ideas.

Keywords: collaborative alliances, rental income, natural resources, economic risks, withdrawal of rent income.

Introduction. In the conditions of market relations, in the presence of competition and occurrence of sometimes unpredictable situations, economic, production or commercial activities are impossible without risks. It is legislatively established that the entrepreneurial activity is risky, that is, the actions of business participants in the conditions of prevailing market relations, competition, functioning of the entire system of economic laws cannot be fully calculated and implemented. This issue is especially relevant in the formation of collaborative alliances in the extractive sector, where the risks can be both objective (external) and subjective (internal). Many decisions in the conditions of collaborative alliances have to be made in conditions of uncertainty, when it is necessary to choose the direction of actions from several possible options, the implementation of which is difficult to predict. In this regard, it is necessary to identify the most significant risks that can qualitatively affect the adoption of a decision and justification for the chosen strategy of economic, investment and financial activity. At the same time, it is important not to avoid risk in general (this is practically impossible), but to study, foresee, evaluate and manage the risks in order to minimize them and, if possible, to turn them into a positive factor in the form of obtaining additional income (Kazakova, 2011). The concept of risk can be defined as the risk of potentially possible, probable loss of resources or shortfall in income in comparison with the option that is designed for rational use of resources in this type of entrepreneurial activity. In other words, risk is a threat that the entrepreneur will incur losses in the form of additional expenses or receive incomes below those for which he/she has expected.

Identification of risks in the creation of collaborative alliances is one of the main factors influencing the interests of alliance members. Risks can be a barrier to solving ecological, economic and social problems for each member of the alliance. The identification of sources of risk has shown that there are factors, phenomena, processes that cause or exacerbate the uncertainty or conflict of the situation and not correspond to the expected results. The uncertain or probabilistic nature of certain processes, events, situations, actions determines that events occur under such conditions, and the impact on the outcome in this case depends on the identification of risk situations, risk management systems, and the quality of the decisions made by the entities. Therefore, it is important to have information about the risks inherent in the economy as a whole or a particular industry and their classification in order to manage them. The first attempts to classify risks appeared a long time, almost with the emergence of the very concept of "risk". A. Marshall is one of the first to classify risks. In the work "Principles of Economic Science," the scientist divided the risk into two types - personal and entrepreneurial. That is, A. Marshall believed that the risk is inherent in both the individual and the legal person. J. Keynes linked the risk classification to the volume of investments and highlighted the risk of the entrepreneur (borrower), the risk of the lender (creditor) and the risk of changing the value of the monetary unit (Keynes J., 1948). The economist also noted that these risks are closely interrelated and "overlap" on each other. J. Schumpeter in his work identifies only two types of risk: 1) connected with the possible technical failure of production, which poses a danger to the loss of goods, generated by natural disasters; 2) caused by the lack of commercial success. As we see, representatives of political economy proceeded from simple economic relations and linked the classification of risks only with entrepreneurial activity. In their works Osadets, Borisova, A. Ogarenko and L. N. Gorbach note that the classification of risks is due to sources of risk (natural and anthropogenic), volume (large and massive) and (catastrophic, large, medium, small and insignificant) risks, the level of their consequences (pure and speculative). That is, the types of insurance risks are the result of accidental events and their consequences. The study of the classification of risks in the accounting is given in the 
works of A. E. Shevelev, E. V. Shevelev and I. M. Vygovskaya. The researchers (Shevelev, Sheveleva, 2008) identify the risks inherent in any type of business entity's business information risk, which is defined as the risk associated with loss and distortion of information, which leads to unexpected losses. Authors (Ostankova, Shevchenko, 2008) based on the systematization of various sources of financial management, risk analysis, analysis theory, choice theory and decision making, classify risks according to nine features: 1) scale and size (global, local); 2) aspects (psychological, social, legal, political, medical and biological, combined); 3) the degree of objectivity and subjectivity of decisions (with objective probability, with subjective probability, with objective-subjective probability); 4) the degree of riskiness of decisions (minimum, acceptable, critical, catastrophic); 5) types of risk (dynamic, static); 6) regarding the timing of making risky decisions (timely, delayed, forward-looking); 7) by the number of decision makers (individual, collective); 8) regarding the situation (stochastic, competing); 9) on the activities of economic entities (production, financial, investment, market) (Ostankova, Shevchenko, 2008).

Risks in the creation of a collaborative alliance for the redistribution of rental income from the extraction of natural resources. For today, the withdrawal and redistribution of rental income from the extraction of natural resources are topical issues in Ukraine. Withdrawal of rental income in accordance with the legislation of Ukraine is a payment for the use and extraction of natural resources for both private and state enterprises and is mandatory for execution. Annually, the rate of rental payments from the extraction of natural resources is steadily growing, while significant revenues are not generated to the regions where natural resources are extracted. The increase in rent payments influences the price increase of the resource, and also influences the competitive policy of the of natural-resource enterprises. In view of the above, there is a need to form a collaborative mechanism that will help to consider the interests of all parties (state, region, enterprise) during resource extraction and coordinate efforts aimed at creating an effective mechanism for the redistribution of rental income from the extraction of natural resources.

The aim of the research is to develop a toolkit for managing a collaborative alliance in the "stateregion-enterprise system" to distribute rental income in the fuel-extracting industry.

In the work, a study was conducted to identify the need for a collaborative alliance between the state and natural extractive enterprises to create socially oriented policies in the regions and redistribution of rental income from the extraction of natural resources. The studies were carried out using the expert evaluation method (questionnaire) among respondents who are directly related to the extraction of natural resources. Conditionally, we divided the respondents into three groups: 1) officials; 2) top managers of companies that extract natural resources; 3 ) representatives of science. There were 320 responses to the questions posed. The obtained results showed that, in addition to the expected positive results from the collaboration, negative effects are also expected (Table 1.1).

First of all, this fear of respondents about the emergence of economic risks in the creation of collaborative alliances, which can affect the cost of resources and competitiveness of extractive enterprises. The respondents also expressed the opinion that excessive extraction of natural resources may be an exhaustion of the resource base of the regions. Considering all of the above, during the additional research, we asked respondents to rank the identified risks by their significance in the formation of the future collaborative alliance in the "state-region-enterprise" system for the distribution of rental income. The obtained results helped to identify the expected risks of the interests of all participants in the Alliance and the main components of the strategy for minimizing the expected negative effects when coordinating the interests of the state and natural-production enterprises, as well as for creating a mechanism of social responsibility through the redistribution of rental income from nature-producing enterprises. 
I. Wiebe, V. Oliinyk, Y. Halynska. Innovative Instrument of Collaborative Alliance Management in the "State-RegionEnterprise" System of Withdrawal of the Rent Income in the Extracting Industry

Table 1 - Identification of risks in the formation of a collaborative alliance in environmental management

\begin{tabular}{|c|c|}
\hline Risk & The cause of the risk \\
\hline $\begin{array}{l}\text { Reducing the price of the } \\
\text { resource }\end{array}$ & $\begin{array}{l}\text { - reduction of shadow business schemes; } \\
\text { - stabilization of business processes; } \\
\text { - competition of products on the domestic and foreign markets; } \\
\text { - state support }\end{array}$ \\
\hline Competition & - will contribute to the increase of the social component of transactions \\
\hline $\begin{array}{l}\text { Increase in rent } \\
\text { payments }\end{array}$ & $\begin{array}{l}\text { - increase in prices for natural resources, formation of uncompetitive prices on the } \\
\text { world market }\end{array}$ \\
\hline $\begin{array}{l}\text { Increase of expenses of } \\
\text { enterprises for extraction } \\
\text { of a unit of natural } \\
\text { resource }\end{array}$ & $\begin{array}{l}\text { - modernization of technological funds of enterprises; } \\
\text { - development of social programs in the regions; } \\
\text { - Implementation of environmental protection measures at enterprises; } \\
\text { - due to increase of rent payments }\end{array}$ \\
\hline $\begin{array}{l}\text { Development of shadow } \\
\text { schemes for determining } \\
\text { rental income }\end{array}$ & - to minimize rent payments to the budget \\
\hline $\begin{array}{l}\text { Increase the price of the } \\
\text { resource }\end{array}$ & $\begin{array}{l}\text { - may be due to additional costs for technological modernization of enterprises, } \\
\text { allocation of new jobs and increase of expenses for the development of social } \\
\text { programs }\end{array}$ \\
\hline $\begin{array}{l}\text { Opportunistic behaviour } \\
\text { of participants }\end{array}$ & - when agreeing on the interests of the parties \\
\hline $\begin{array}{l}\text { State control over key } \\
\text { sectors of the economy } \\
\text { that generate significant } \\
\text { rental income }\end{array}$ & - monopolization of the industry \\
\hline $\begin{array}{l}\text { Necessary changes in } \\
\text { the legislative framework }\end{array}$ & $\begin{array}{l}\text { - the conclusion of collaborative alliances between the state and nature } \\
\text { enterprises and harmonization of interests of parties with definition of social } \\
\text { responsibility of all parties to the agreement will entail changes in the legislative } \\
\text { framework }\end{array}$ \\
\hline
\end{tabular}

According to the respondents' assessment, the risk factor was determined and the probability of occurrence of the event (risk) was calculated during the implementation of the collaboration mechanism (Table 2). The ranking coefficient was calculated by the method of averaged advantage in the presence of several experts. The method assumes that each criterion is assigned an estimate equal to the criterion's place in a series of advantages, and a ranking factor is determined by dividing the sum of the criterion's estimates by the total sum of the estimates of all the criteria of all experts

To determine the relationship between quantitative and qualitative characteristics that characterize homogeneous ranked objects in the work, the rank coefficient of concordation M. Kendall - B. Smith uses. Its essence lies in the fact that each property of an object is assigned its own rank. Moreover, each expert included in the expert group, this rank is assigned on its own, as a result of this there is a need to process these data in order to identify the consistency of expert opinions. This process is carried out by calculating the coefficient of concordance.

The level of mutual agreement of expert opinions influences the correctness of the results of the performed examination. The consistency of expert opinion is usually calculated with the help of M. Kendall and B. Smith's concordation factor. This assessment is needed primarily because experts' opinions can vary greatly according to the estimated parameters. Initially, evaluations are carried out by ranking indicators and assigning them a certain coefficient of significance (weight). An uncoordinated ranking lead to the fact that these coefficients will be statistically false. 
Table 2 - Probability of risk events in the implementation of the collaborative mechanism in environmental management

\begin{tabular}{|l|c|c|}
\hline \multicolumn{1}{|c|}{ Reason } & Ranking factor & $\begin{array}{c}\text { The probability of occurrence of } \\
\text { an event when implementing a } \\
\text { collaborative alliance }\end{array}$ \\
\hline Increase the price of the resource & 0,4 & 0,22 \\
\hline Reducing the price of the resource & 0,9 & 0,34 \\
\hline Increase in the amount of rent payments & 0,7 & 0,42 \\
\hline $\begin{array}{l}\text { Development of shadow schemes for } \\
\text { determining rental income }\end{array}$ & 0,4 & 0,27 \\
\hline Depletion of the resources of the region & 0,1 & 0,48 \\
\hline $\begin{array}{l}\text { Increase of expenses of enterprises for } \\
\text { extraction of a unit of a natural resource }\end{array}$ & 0,6 & 0,52 \\
\hline $\begin{array}{l}\text { Opportunistic behavior of participants during } \\
\text { the coordination of the parties' interests }\end{array}$ & 0,3 & 0,25 \\
\hline $\begin{array}{l}\text { Competition will help increase the social } \\
\text { component of transactions }\end{array}$ & 0,8 & 0,47 \\
\hline $\begin{array}{l}\text { State control over key sectors of the } \\
\text { economy }\end{array}$ & 0,2 & 0,1 \\
\hline $\begin{array}{l}\text { Necessary changes in the legislative } \\
\text { framework }\end{array}$ & 0,1 & 0,5 \\
\hline
\end{tabular}

The coefficient is a dimensionless value that shows the ratio in the general case of variance to the maximum dispersion. The coefficient of concordance is the number from 0 to 1 , which shows the consistency of expert opinions during the rendering of some properties. The closer this value to 0 , the consistency is considered lower. For the value of this coefficient, less than 0.3 experts' opinions are considered inconsistent. When the value of the coefficient is found in the range from 0,3 to 0,7 , the consistency is considered average. For values greater than 0.7 , consistency is high. The consistency of the ranking made by the experts must be determined to confirm the correctness of the hypothesis that the experts make relatively precise measurements that allow forming different groups in expert groups that are conditioned by human factors, in particular such as the difference between views, concepts, different scholarly schools, the nature professional activity, etc.

This coefficient is defined by the formula $t=2 S /(n(n-1))$, where $S$ is the sum of the differences between the number of sequences and the number of inversions by the second sign; $n$ - number of observations.

The main advantage of the rank method is the ease of implementation. The main drawbacks of the method are: a small number of objects of ranking, since when exceeding their number of 15-20 it becomes difficult to assign objective rank assessments; on the basis of the use of this method remains an open question about how far the significance of the objects being investigated from each other.

The results of the questionnaire, conducted in 2016-2017 years, were used in the paper, concerning the necessity of implementing cooperation alliances in the field of nature management. Respondents ranked the significance of the results of the questionnaire responses. N. M. Aikozhaev in the article "Assessment of the degree of consistency of expert opinions" suggests the use of the following formulas for calculating the coefficient of concordation:

$$
D_{\max }=\frac{d_{2}\left(m_{3}-n\right)}{12(m-1)}
$$


I. Wiebe, V. Oliinyk, Y. Halynska. Innovative Instrument of Collaborative Alliance Management in the "State-RegionEnterprise" System of Withdrawal of the Rent Income in the Extracting Industry

$$
\begin{aligned}
& D_{\max }=\frac{1}{m-1} \sum_{i=1}^{m}\left(r_{i}-r\right)^{2} \\
& R=\frac{1}{m} \sum_{i=1}^{m} r_{i} \\
& S=\sum_{i=1}^{m}\left(\sum_{S=1}^{d} r_{i s}-r\right)^{2} \\
& D=\frac{1}{m-1} \times S
\end{aligned}
$$

where rcp - estimation of mathematical expectation; $m$ is the number of objects.

Substituting the resulting formulas in the ratio $D$ to Dmax, we obtain the final formula for the concordance coefficient:

$$
\begin{aligned}
& W=\frac{2 S}{m 2(n 3-n)} \\
& W=\frac{12 S}{\mathrm{~m} 2(\mathrm{n} 3-\mathrm{n})-m \sum_{j=1}^{m} T j}
\end{aligned}
$$

where $\mathrm{m}$ - number of experts; $\mathrm{n}$ is the number of objects.

The first formula is used to determine the coefficient of concordation, if there are no related ranks. The second formula is used if there are related ranks (related ranks in the event that the same expert with different properties are subject to the same ranks). The obtained criterion is compared with the table values, and when the value of the first over the last one is exceeded, they say about the significance of the investigated coefficient. The results of the study are presented in Table. 3.

Table 3 - Calculations of the coefficient of concordation M. Kendall - B. Smith

\begin{tabular}{|c|c|c|c|c|c|c|}
\hline & \multicolumn{5}{|c|}{ The number of respondents' answers on the significance of the question } \\
\hline Question number & $\begin{array}{c}\text { Not } \\
\text { important }\end{array}$ & Allowed & Has the meaning & Important & Very important & Amount \\
\hline 1 & 2 & 9 & 9 & 9 & 3 & \\
\hline 2 & 1 & 2 & 5 & 9 & 15 & \\
\hline 3 & 1 & 3 & 7 & 15 & 6 & \\
\hline 4 & 1 & 3 & 4 & 4 & 20 & \\
\hline 5 & 1 & 2 & 5 & 9 & 15 & \\
\hline 6 & 1 & 1 & 3 & 6 & 21 & \\
\hline 7 & 1 & 2 & 6 & 8 & 15 & \\
\hline 8 & 1 & 10 & 8 & 9 & 4 & \\
\hline 9 & 3 & 4 & 7 & 4 & 14 & \\
\hline 10 & 2 & 7 & 7 & 9 & 7 & \\
\hline$\sum$ ris & 14 & 43 & 61 & 82 & 120 & 320 \\
\hline rcp & & & & & & 64 \\
\hline $\begin{array}{c}\text { The difference } \\
\text { between ris and rcp }\end{array}$ & -50 & -21 & -3 & 18 & 56 & \\
\hline Squared difference & 2500 & 441 & 9 & 324 & 3136 & 6410 \\
\hline W & & & & & & 0,766 \\
\hline
\end{tabular}

The results of the calculation showed that the coefficient of experts' concordance in identifying risks in the creation of a collaborative alliance is 0.766 , which means that the consistency of experts is high enough because it corresponds to the normative value. $\mathrm{W}>0,6-0,8$, if $\mathrm{W}<0,2-0,4$, this means weak coordination of experts.

The conducted studies have shown that most decisions in the activities of the cooperative alliances 
are adopted in conditions of uncertainty and unpredictability. As the respondents expressed the assumption that most of the identified risks have a fuzzy logic, the scientific-methodical approach to ranking social, economic and environmental risks in the creation of collaborative alliances in the fuelextracting industry, based on the application of Fuzzy Logic method and considering indicators of the stability of collaborative relationships in identifying the most significant risks and their interdependencies.

The main idea of this research is to define the significance of the identified risks and to combine them into the dependence groups upon the formation of collaboration alliances in the extracting industry.

The method objective - ranking the risks identified by the respondents is of subjective nature and the experts cannot often determine the rank of a particular indicator in their answers (for example, "important" or "very important" for the alliance formation). Therefore, the main objective of this study is to model the mathematical model to determine the most significant economic risks and their influence on the formation of collaboration alliance between the state and the extracting companies.

Applied aspect - the definition of risks significance for the collaboration alliance will help in the future to form the strategy of implementation of the collaboration mechanism in the formation of socially-oriented policy in the regions.

Method. Based on a critical analysis of the existing methods we offered a scientific and methodical approach to determining the risks significance in the formation of collaboration mechanism regarding the redistribution of natural resource rent. It should be noted that it is necessary to allocate such requirement to this model: the experts individually determine the significance of risks for the research results.

It should be noted that the modelling methods include: creation of data array, implementation of arithmetic calculations, possibility of obtaining results upon logical conditions, implementation of comparative characteristics. The software for the implementation of this model can act the software package MathCAD.

To construct this model, firstly, it is necessary to analyse the input information for simulation, which will be represented by the expert opinions of the respondents. To implement this task, we offer to use the indicators, which are based on the use of Fuzzy Logic tools. The concept of Fuzzy Logic is an attempt of mathematical formalization of fuzzy information for constructing the mathematical models. This concept is based on the notion that the elements composing a given set possessing a common property can possess this property in different degrees and, consequently, belong to a given set with different degrees. With such an approach, statements such as "such an element belongs to a given set" lose their meaning, since it is necessary to indicate "how much" or to what degree a particular element satisfies the properties of a given set. Since our respondents expressed an assumption about the significance of the identified risks, we attempted to formalize the results obtained through a mathematical model.

The figure includes the following conditional risk meanings:

$X_{1}$-decrease in the resource price;

$X_{2}$ - competition will increase the social component in the contracts;

$X_{3}-$ increase in the amount of rent payments;

$X_{4}$ - increase in the costs of companies for extraction of a natural resource unit;

$X_{5}$ - development of shadow schemes for determining the rental income;

$X_{6}$-increase in the resource price;

$X_{7}$-opportunistic behaviour of the parties upon the negotiation of interests;

$X_{8}$-state control over the key sectors of economy, which form a significant rental income;

$X_{9}-$ resource depletion in the region;

$X_{10}-$ necessary changes in the legislative framework.

The proposed model includes a defined set of quantitative and qualitative (quantitative) indicators with the general number of $n$. As a result of the expert uncertainty there are fuzzy explanations in the model structure, which appear at the index level classification. For example, the expert cannot clearly distinguish 
I. Wiebe, V. Oliinyk, Y. Halynska. Innovative Instrument of Collaborative Alliance Management in the "State-RegionEnterprise" System of Withdrawal of the Rent Income in the Extracting Industry

the concepts of "important" and "very important" for the formation of collaboration alliance. In such situation, the application of fuzzy descriptions (explanations) means the following:

- the expert fixes the indicator and its quantitative media (if any);

- on the selected media the expert builds a linguistic variable with its term-set of values with the general number of $m$. For example: a variable "indicator level $X "$ can have the following term-set of values $(m=5)$ : "not important, permissible, has some importance, important, very important". If there is no quantitative assessment, then the expert only fixes the indicator value from the existing term-set of values with a corresponding probability.

If there is a quantitative assessment of indicator, the expert compares the membership function of management level of a particular fuzzy set with each value of the linguistic variable.

In this case, the commonly used functions are the trapezoidal membership functions (Fig. 2). It should be made some specifications: the upper trapeze limit corresponds to full confidence of the expert in the correctness of his/her classification, and the lower - to confidence that no other interval meanings $[0,1]$ do not fall within the selected fuzzy subset.

First stage. It is called "Linguistic variables and fuzzy subsets".

a. Linguistic factor $V$ "The expected indicator value" has the following 5 meanings: $V_{1}$ - fuzzy subset "expected value is very low"; $V_{2}$ - fuzzy subset "expected value is low"; $V_{3}$ - fuzzy subset "expected value is average"; $V_{4}$ - fuzzy subset "expected value is high"; $V_{5}$ - fuzzy subset "expected value is very high". It should be noted that the set carrier $V$-- is the expected value of the indicator. For any single financial or management indicator $x_{i}$ we set a linguistic variable $B_{i}-$ "Indicator level $x_{i}$ " on the following term-set of values: $B_{i 1}$ - subset "not important $x_{i}^{\prime \prime}$; $B_{i 2}$ - subset "permissible $x_{i}^{\prime \prime} ; B_{i 3}$ - subset "has some importance $x_{i}^{\prime \prime}$; $\mathrm{B}_{i 4}$ - subset "important $x_{i}$ "; $\mathrm{B}_{i 5}$ - subset "very important $x_{i}$ ".

Stage 1: Identification of the risks that have been identified by the respondents in the formation of collaboration alliance

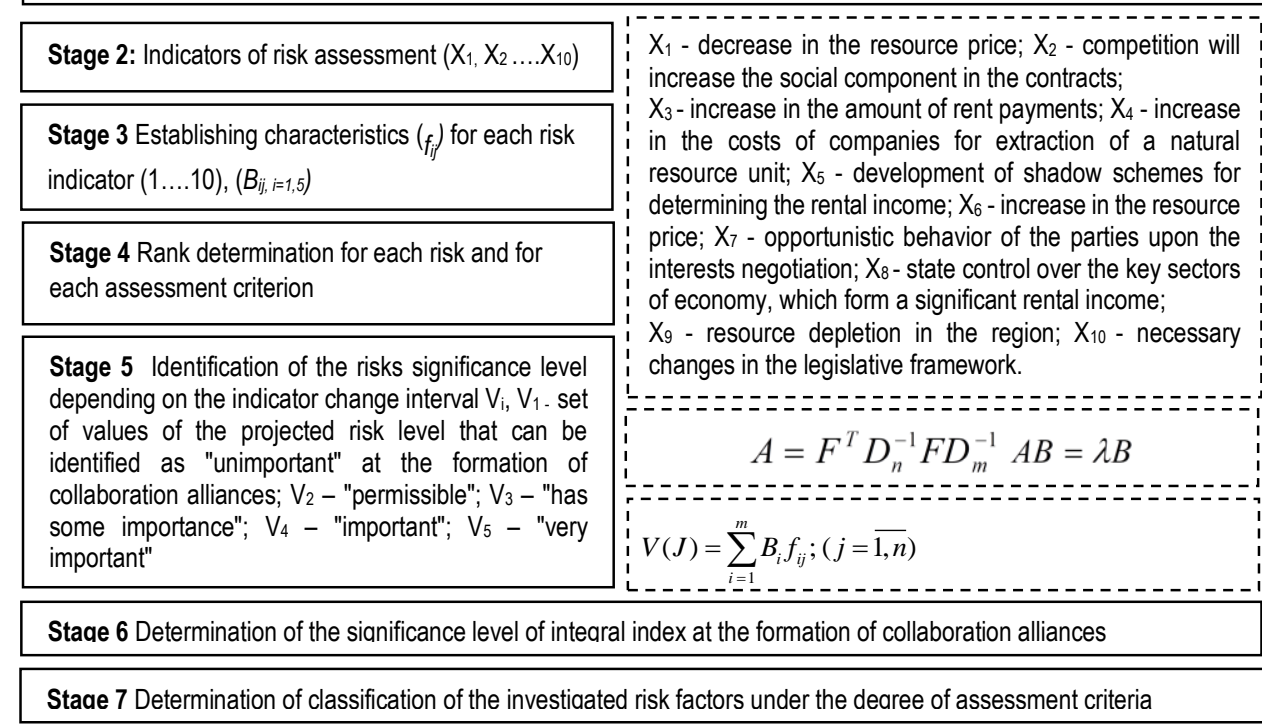

Figure 1 - Algorithm for determining the significance of identified risks and their interdependence on the basis of Fuzzy Logic Theory

Second stage. "Determining the degree of confidence of a person on the basis of the membership 
function". To do this, each factor $\mathrm{V}$, defined in the previous stage, shall be assigned with the membership function.

In the context of this classification, it is necessary to add that the fuzzy subset differs from the ordinary one by the fact that for elements $x$ from $V$ there is no clear answer "no" regarding the properties of $x$. In connection with this, a fuzzy subset $A$ of the universal set $V$ is determined as a set of ordered pair $A=\{x$; $\mu\}$, where $\mu$-characteristic membership function (or membership function) and it characterizes the degree of confidence with respect to the expected factor level obtained. To find the expected factor value we will use the correspondence analysis method. In order to do this we generalize the expert opinions for each indicator of this study. The received data shall be entered in Table 1. It should be noted that the expert opinions on the quality of each variable may be subject to the laws of fuzzy logic, that is, the expert may include the factor studied to different levels of assessment in accordance with his/her wishes.

This approach enables to get the numerical values of quality of the test feature, and then to derive the expected (average) values of the test features on their basis. In accordance with Table 2 it is possible to find a numerical evaluation of the factors studied as a membership function. Analyzing the obtained values, we can evaluate each factor and assess their contribution to the studied phenomenon or process.

Result. Let us consider the mathematical algorithm for finding the numerical values of non-numeric information on quality of a separate feature.

For any single financial or management indicator $x_{i}$ we set a linguistic variable $\mathrm{B}_{i}-$ "Indicator level $\mathrm{x}_{i}$ on the following term-set of values:

$B_{i 1}$ - subset "not important $x_{i}^{\prime \prime} ; B_{i 2}$ - subset "permissible $x_{i}$; $B_{i 3}$ - subset "has some importance $x_{i}$ "; $B_{i 4}$ - subset "important $x_{i}$ "; $B_{i 5}$ - subset "very important $x_{i}$ ".

Then we find the numerical values $B_{i j}$, which represent the interrelationship of signs in the best way so as to maximize the connection closeness indicator between two signs. On the basis of Table 1, we consider the adjacency matrix $F$ of signs $X$ and $B$

$$
F=\left[\begin{array}{cccc}
f_{11} & f_{12} & \cdots & f_{1 m} \\
\cdots & \cdots & \cdots & \cdots \\
f_{n 1} & f_{n 2} & \cdots & f_{n m}
\end{array}\right]
$$

Let us consider the diagonal matrices $D_{n}$ and $D_{m}$.

$$
D_{n}=\left[\begin{array}{cccc}
c_{1} & 0 & \cdots & 0 \\
0 & c_{2} & \cdots & 0 \\
\cdots & \cdots & \cdots & \cdots \\
0 & 0 & 0 & c_{n}
\end{array}\right] ; \quad D_{m}=\left[\begin{array}{cccc}
s_{1} & 0 & \cdots & 0 \\
0 & s_{2} & \cdots & 0 \\
\cdots & \cdots & \cdots & \cdots \\
0 & 0 & 0 & s_{m}
\end{array}\right]
$$

where $c_{i}=\sum_{j=1}^{m} f_{i j} ; s_{j}=\sum_{i=1}^{n} f_{i j}$.

We find the eigenvalues $\lambda$ of matrix $A=F^{T} D_{n}^{-1} F D_{m}^{-1}$, that is, the roots of characteristic equation

$$
\operatorname{det}|A-\lambda l|=0
$$

where $F^{T}$ - transposed matrix; $D_{n}^{-1} ; D_{m}^{-1}$ - inverse corresponding matrices; I - single matrix.

The number of matrix eigenvalues is equal to its rank. If $q=\operatorname{rang} A$, then we receive for the solution 
set of the characteristic equation:

$$
\lambda_{1}>\lambda_{2}>\ldots>\lambda_{q}
$$

The desired solution is the coordinates of eigenvector $B$ of matrix $A$, which are found from the system of linear equations $A B=\lambda B$. From the set of admissible eigenvalues of matrix $A$ we select the eigen vector as a primary one, which satisfies the ratio:

$$
\lambda=\lambda_{1}=\max \lambda_{i}, i=\overline{1, q} .
$$

We can judge how well the resulting solution established the correspondence between the features by the ratio:

$$
L=\frac{\lambda_{1}}{S p A}
$$

where $\operatorname{Tr} A=\operatorname{Sp} A=\sum_{i=1}^{m} \lambda_{i}=\sum_{i=1}^{m} a_{i i}$ - matrix trace $A$. The closer $L$ to one is, the more accurate the resulting solution is. Let us find the value of linguistic factor $V$ "The expected indicator value" for each of the studied $n$ factors:

$$
V(J)=\sum_{i=1}^{m} B_{i} f_{i j} ;(j=\overline{1, n})
$$

In this model, a summary table of assessment of the studied phenomenon was based on a survey of 32 experts. The quality of test process was assessed on the basis of 10 indicators (questions).

The experts estimate each risk factor with a certain probability for each evaluation criterion. Factor $X_{1}$ is evaluated with the probability of $30 \%$ under the criterion "permissible" and of $70 \%$ under the criterion "has some importance" -. Factor $X_{2}$ is evaluated with the probability of $90 \%$ under the criterion "has some importance" and 10\% under the criterion "important", etc. In this case, the criteria determine the degree of importance of each risk in the formation of collaboration alliance between the state and the extracting companies. The desired solution is the coordinates of eigenvector $B$ of matrix $A$, which are found from the system of linear equations $A B=\lambda_{1} B: \mathrm{B}_{1}=0,086 ; \mathrm{B}_{2}=0,263 ; \mathrm{B}_{3}=0,372 ; \mathrm{B}_{4}=0,5 ; \mathrm{B}_{5}=0,737$. Let us define how well the resulting solution establishes the correspondence between the features:

$$
L=\frac{\lambda_{1}}{\operatorname{SpA}}=0,818
$$

Let us find the value of linguistic factor $V$ "The expected indicator value" for each of the studied $n$ factors: $V(J)=\sum_{i=1}^{5} B_{i} f_{i j} ;(j=\overline{1, n})$.

The resulting "expected value" of each factor has helped us to rank the risks in order of their importance. Thus, we can build the risk factors in order of their importance:

1. Increase in the resource price;

2. Increase in the costs of companies for extraction of a natural resource unit; 
3. Competition between the extracting companies;

4. Development of shadow schemes for determining the rental income;

5. Opportunistic behaviour of the parties upon the negotiation of interests;

6. Resource depletion in the region;

7. Increase in the amount of rent payments;

8. Necessary changes in the legislative framework;

9. State control over the key sectors of economy, which form a significant rental income;

10. Decrease in the resource price.

Table 4 - The value of linguistic factor V "The expected indicator value"

\begin{tabular}{|l|l|l|l|}
\hline No. & Variable studied & Meaning of indicator V & Rank \\
\hline 1 & $X_{1}$ & 0.395 & 10 \\
\hline 2 & $X_{2}$ & 0.561 & 3 \\
\hline 3 & $X_{3}$ & 0.479 & 7 \\
\hline 4 & $X_{4}$ & 0.595 & 2 \\
\hline 5 & $X_{5}$ & 0.560 & 4 \\
\hline 6 & $X_{6}$ & 0.616 & 1 \\
\hline 7 & $X_{7}$ & 0.553 & 5 \\
\hline 8 & $X_{8}$ & 0.412 & 9 \\
\hline 9 & $X_{9}$ & 0.507 & 6 \\
\hline 10 & $X_{10}$ & 0.448 & 8 \\
\hline
\end{tabular}

To identify the obtained values, we consider the membership function for the studied variables (Table 5). The membership function shows the value of integral indicator of expert opinions to the expected value.

Table 5 - Membership function and classification current factor value

\begin{tabular}{|c|c|c|}
\hline Interval of values $\mathrm{V}$ & Classification of the factor level & Level of confidence \\
\hline $0,086 \leq \mathrm{V} \leq 0,129$ & $\mathrm{~V}_{1}$ & 1 \\
\hline \multirow{2}{*}{$0,129<\mathrm{V}<0,217$} & $\mathrm{~V}_{1}$ & $\mu_{1}=11,363(0,217-\mathrm{V})$ \\
\hline $0,217 \leq \mathrm{V} \leq 0,289$ & $\mathrm{~V}_{2}$ & $1-\mu_{1}=\mu_{2}$ \\
\hline \multirow{2}{*}{$0,289<\mathrm{V}<0,344$} & $\mathrm{~V}_{2}$ & 1 \\
\cline { 2 - 3 } & $\mathrm{V}_{2}$ & $\mu_{2}=18,182(0,344-\mathrm{V})$ \\
\hline $0,344 \leq \mathrm{V} \leq 0,404$ & $\mathrm{~V}_{3}$ & $1-\mu_{2}=\mu_{3}$ \\
\hline \multirow{2}{*}{$0,404<\mathrm{V}<0,468$} & $\mathrm{~V}_{3}$ & 1 \\
\hline $0,468 \leq \mathrm{V} \leq 0,558$ & $\mathrm{~V}_{3}$ & $\mu_{3}=15,625(0,468-\mathrm{V})$ \\
\hline \multirow{2}{*}{$0,558<\mathrm{V}<0,673$} & $\mathrm{~V}_{4}$ & $1-\mu_{3}=\mu_{4}$ \\
\cline { 2 - 3 } & $\mathrm{V}_{4}$ & 1 \\
\hline $0,673 \leq \mathrm{V} \leq 0,737$ & $\mathrm{~V}_{4}$ & $\mu_{4}=8,695(0,673-\mathrm{V})$ \\
\hline
\end{tabular}

In accordance with the classification of studied variables offered in Table 3, based on the received values (Table 4, we will obtain the table of final analysis of the studied variables. Applying the membership function, we were able not only to rank the factors by the degree of significance for the formation of 
I. Wiebe, V. Oliinyk, Y. Halynska. Innovative Instrument of Collaborative Alliance Management in the "State-RegionEnterprise" System of Withdrawal of the Rent Income in the Extracting Industry

collaborative alliances, but also to combine them into groups, thus defining the direction of strategies in the implementation of the collaborative mechanisms. The first group of risks that can be assessed as "very important" for collaboration alliances include: an increase in the enterprise's cost of extracting a unit of resource -0.32 ; increase in the price of the resource $-0,50$.

Table 6-Classification of the studied factors

\begin{tabular}{|c|c|c|c|c|c|c|c|}
\hline \multirow[b]{2}{*}{ No. } & \multirow[b]{2}{*}{ Name of variable } & \multicolumn{5}{|c|}{ Expected value } & \multirow[t]{2}{*}{ Rank } \\
\hline & & $\begin{array}{c}\text { Not } \\
\text { important }\end{array}$ & \begin{tabular}{|c|} 
Permis \\
sible
\end{tabular} & $\begin{array}{l}\text { Has some } \\
\text { importance }\end{array}$ & Important & $\begin{array}{c}\text { Very } \\
\text { important }\end{array}$ & \\
\hline 1 & Decrease in the resource price & & & 0.395 & & & 10 \\
\hline \multirow[b]{2}{*}{2} & \multirow{2}{*}{$\begin{array}{l}\text { Competition will increase the social } \\
\text { component in the contracts }\end{array}$} & & & & \multicolumn{2}{|l|}{0.561} & 3 \\
\hline & & & & & 0.97 & 0.03 & \\
\hline \multirow{2}{*}{3} & \multirow{2}{*}{$\begin{array}{l}\text { Increase in the amount of rent } \\
\text { payments }\end{array}$} & & & & 0.479 & & \multirow{2}{*}{7} \\
\hline & & & & & 1.0 & & \\
\hline \multirow[b]{2}{*}{4} & \multirow{2}{*}{$\begin{array}{l}\text { Increase in the costs of companies } \\
\text { for extraction of a natural resource } \\
\text { unit }\end{array}$} & & & & \multicolumn{2}{|l|}{0.595} & 2 \\
\hline & & & & & 0.68 & 0.32 & \\
\hline \multirow{2}{*}{5} & \multirow{2}{*}{$\begin{array}{l}\text { Development of shadow schemes } \\
\text { for determining the rental income }\end{array}$} & & & & \multicolumn{2}{|l|}{0.560} & 4 \\
\hline & & & & & 0.98 & 0.02 & \\
\hline \multirow{2}{*}{6} & \multirow{2}{*}{ Increase in the resource price } & & & & \multicolumn{2}{|l|}{0.616} & 1 \\
\hline & & & & & 0.50 & 0.50 & \\
\hline \multirow[b]{2}{*}{7} & \multirow{2}{*}{$\begin{array}{l}\text { Opportunistic behaviour of the } \\
\text { parties upon the interests } \\
\text { negotiation }\end{array}$} & & & & 0.553 & & \multirow[b]{2}{*}{5} \\
\hline & & & & & 1.0 & & \\
\hline \multirow[b]{2}{*}{8} & \multirow{2}{*}{$\begin{array}{l}\text { State control over the key sectors of } \\
\text { economy, which form a significant } \\
\text { rental income }\end{array}$} & & & \multicolumn{2}{|l|}{0.412} & & \multirow[b]{2}{*}{9} \\
\hline & & & & 0.88 & 0.12 & & \\
\hline \multirow{2}{*}{9} & \multirow{2}{*}{ Resource depletion in the region } & & & & 0.507 & & \multirow{2}{*}{6} \\
\hline & & & & & 1.0 & & \\
\hline \multirow{2}{*}{10} & \multirow{2}{*}{$\begin{array}{l}\text { Necessary changes in the legislative } \\
\text { framework }\end{array}$} & & & \multicolumn{2}{|l|}{0.448} & & 8 \\
\hline & & & & 0.31 & 0.69 & & 8 \\
\hline
\end{tabular}

The second group according to the criterion is "important": the competition between extractive enterprises $-0,97$; increase in the amount of rent payments $-1,0$; opportunistic behaviour of participants during the coordination of the parties' interests - 1.0; depletion of resources of regions $-1,0$; the development of shadow schemes in determining the rental income $-0,98$.

To the third group of risks according to the criterion "matters" can be attributed: a decrease in the price of the resource $-1,0$ and state control over key sectors of the economy $-0,88$.

Ranking these risks by the degree of significance during the formation of a collaborative alliance between the state and nature-resources enterprises on the distribution of natural rent and their grouping in terms of the degree of impact on the final result will help us in the future to formulate a strategy for the implementation of a collaborative mechanism to create a socially-oriented policy through the distribution of rental income from the extraction of natural resources.

Also, using the method of fuzzy logic with the definition of the membership function of the data under study, the interdependence of risk factors in the functioning of the collaborative alliances in the system "state-region-enterprise" was determined in the work (Table 7).

Accounting for the interdependence of risk factors will help in the formation of strategies for the development of collaborative alliances in a particular region. When a certain risk occurs, there is a 
probability of another with a certain percentage. For example, the emergence of the risk of state control over key sectors of the economy that generate significant rental income is 0.88 percent, while the risk is an interrelated risk - an increase in the amount of rent payments that can occur with a probability of 0.12 percent. Thus, considering the interdependence of risk factors, we minimize their onset in the formation and functioning of collaborative alliances.

Table 7 - Significance and interdependence of risk factors of collaborative alliances in the "state-region-enterprise" system

\begin{tabular}{|c|c|c|c|c|c|}
\hline $\begin{array}{l}\text { Le } \\
\text { vel }\end{array}$ & \multicolumn{2}{|c|}{$\begin{array}{l}\text { Risks in the creation of collaborative } \\
\text { alliances in environmental management }\end{array}$} & \multicolumn{2}{|c|}{$\begin{array}{l}\text { Expected value } \\
\text { of interrelations } \\
\text { of factors }\end{array}$} & Interdependence of risk factors \\
\hline \multirow{5}{*}{$\frac{\Phi}{\oplus \pi}$} & 1. & Decrease in resource price & \multicolumn{2}{|c|}{1.0} & $\begin{array}{ll}\text { Opportunistic } & \text { behavior } \\
\text { participants } & \end{array}$ \\
\hline & 2. & $\begin{array}{l}\text { Development of shadow schemes in } \\
\text { determining rental income }\end{array}$ & 0.98 & 0.02 & $\begin{array}{l}\text { Changes in the legislative } \\
\text { framework }\end{array}$ \\
\hline & 3. & Increase in the price of the resource & 0.50 & 0.50 & Depletion of regional resources \\
\hline & 4. & $\begin{array}{l}\text { State control over key sectors of the } \\
\text { economy, form a significant rental } \\
\text { income }\end{array}$ & 0.88 & 0.12 & $\begin{array}{l}\text { Increase in the amount of rent } \\
\text { payments }\end{array}$ \\
\hline & 5. & Changes in the legislative framework & 0.31 & 0.69 & $\begin{array}{l}\text { Development of shadow schemes } \\
\text { in determining rental income }\end{array}$ \\
\hline \multirow{3}{*}{ 흥 } & 6. & $\begin{array}{l}\text { Competition will increase the social } \\
\text { factor with the harmonization of the } \\
\text { interests of the parties }\end{array}$ & 0.67 & 0.33 & $\begin{array}{l}\text { Increase in the costs of enterprises } \\
\text { to extract a resource unit }\end{array}$ \\
\hline & 7. & Depletion of regional resources & 0.50 & 0.50 & Increase in the price of the resource \\
\hline & 8. & Increase in the price of the resource & 0.72 & 0.28 & $\begin{array}{l}\text { State control over key sectors of the } \\
\text { economy, form a significant rental } \\
\text { income }\end{array}$ \\
\hline \multirow{4}{*}{ 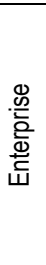 } & 9. & $\begin{array}{l}\text { Increase in the amount of rent } \\
\text { payments }\end{array}$ & 0.23 & 0.77 & $\begin{array}{l}\text { Development of shadow schemes } \\
\text { in determining rental income }\end{array}$ \\
\hline & 10. & $\begin{array}{l}\text { Opportunistic behaviour of } \\
\text { participants }\end{array}$ & 0.33 & 0.67 & Conflict of interest of participants \\
\hline & 11. & $\begin{array}{l}\text { Increase in the costs of enterprises to } \\
\text { extract a resource unit }\end{array}$ & \multicolumn{2}{|l|}{1.0} & Increase in the price of the resource \\
\hline & 12. & Increase in the price of the resource & 0.55 & 0.45 & $\begin{array}{l}\text { Competition of companies will } \\
\text { negatively affect public interests }\end{array}$ \\
\hline
\end{tabular}

The ranking of these risks in order of their importance upon the formation of collaboration alliance between the state and the extracting companies regarding the distribution of natural resource rent and their combination into the dependence groups on the degree of influence on the end result will help us to form a strategy for the implementation of collaboration mechanism in the future to create a sociallyoriented policy through the distribution of rental income from the extraction of natural resources.

Thus, the results of our study have showed that the collaboration can be a tool that helps coordinate all efforts aimed at creating an effective mechanism for redistributing rental income from the extraction of natural resources.

As researches show, the majority of respondents (representatives of extractive business, universities of professors) have tried to objectively assess the situation in the executive industry of Ukraine and suppose that to receive a positive effect of cooperation in the future, it is necessary to incur certain costs and invest an effort at the initial stage of cooperation.

This is primarily due to:

- Cultural differences, the concept of cooperation is negative and involves co-operation for the representatives of Eastern Europe (Ukraine, Poland, Slovenia, Romania, Belarus). Accordingly, this 
I. Wiebe, V. Oliinyk, Y. Halynska. Innovative Instrument of Collaborative Alliance Management in the "State-RegionEnterprise" System of Withdrawal of the Rent Income in the Extracting Industry

cooperation is limited to one project, without further interaction between the participants;

- - - Increasing the company costs to extract an additional unit of resources and increasing competition among companies in the external market will directly affect competition in the domestic market, which will lead to business combination and creation of alliances. In turn, competition between private and public companies is inevitable in the process of joint work, which can lead to higher prices in connection with an increase in the costs of companies in the production of an additional resource unit. This business strategy can lead to depletion of the resource base of the region and deterioration of the economic situation in the region of extraction.

The reconciliation of interests of the state and the extracting companies will promote the development of new programs of social and strategic orientation at the state level and at the regional level, which will result in the development of compensation programs for the producing regions in order to form social responsibility in the redistribution of rental income.

Nevertheless, the majority of respondents believe that cooperation can be a negative effect for all participants at an early stage.

Arthur T. Himmelman, Working Together: Coordinating, Cooperating, Or Collaborating, 2002, Access on: https://leadingdifferently.com/2015/01/14/working-together-coordinating-cooperating-or-collaborating/.

Annett Schottle, Shervin Haghsheno, Fritz Gehbauer. (2013). Defining cooperation and collaboration in the context of lean construction?

Hudáková m., Schönfeld j., Dvorský j., Lusková M. The Market Risk Analysis and Methodology of its More Effective Management in Smes in the Slovak Republic. Montenegrin Journal of Economics Vol. 13, No. 2 (2017), 151-161.

Keynes J. M. The general theory of employment, interest and money - Moscow, 1948. - 253 p.

Klishyna Yu.N. The Use of Correspondence Analysis in the Treatment of Non-Numerical Information. Sociology: 4M. 1991, 2 P. 105-118.

Ostankova L. A., Shevchenko N. Yu. Analysis, modeling and management of economic risks: teaching. manual - Kyiv: Center for Educational Literature, 2011. - 256 p.

Osadchaya I. Natural rent, superprints of oil monopolies and state. - Access mode: http://www.nkj.ru/archive/articles/4196/

Law of Ukraine on 20.05.2010, BD, 2010, N 30, st.398\} About Rent Payments for Oil, Natural Gas and gas condensate. Access mode http://zakon2.rada.gov.ua/laws/show/1456-15.

Marshall A. Principles of Economic Science: 2 t. Moscow: Progress-Universe, 1993. 458 p.

Schumpeter I. The theory of economic development. Studies of entrepreneurial profit, capital, credit, interest and the cycle of the conjuncture. Moscow, 1982

Kazakova N. Economic analysis in business valuation: textbook / N. Kazakova, M.: Delo I Servis,2011. - 288 p.

Nedosekin A. O., Maksimov O. B.New Comprehensive Indicator for Assessing the Financial Condition of the Company. Access mode: http://www.vmgroup.sp.ru/Win/index1.htm.

Shevelev A. Ye. Risks in Accounting: Textbook. - 2 nd ed., Revised and updated. - Moscow: KNORUS, 2008. - 304 p.

Jaroslaw K. Ponder Managing Risk in the Competitive Environment of the Telecommunication Sector Report on the Expert Dialogues Meeting that took place in Geneva, Switzerland 28-29 October 2004.

Jouni Huotari, Ilkka Turunen, Piotr Krawczyk, Open Collaboration wthin living Lab as an Ecosystem: an insight from SME CEO's

Perspective. - Access mode http://www.juuli.fi/Record/juuli2011_2014-110.

Risks and uncertainties associated with the competitive environment in the European natural gas market. Access mode: http://www.eni.com/en IT/investor-relation/presentations-reports/.

Shtovba S. D. Design of control systems. Fuzzy Logic. - Access mode ftp://ftp.vt.tpu.ru/study/Spitsyn/public/from\%20Tzoy/Comp\%20Intelligence/lectures/reading/С.Д.Штовба.

Shizuhiro Nishisato. Analysis of Categorical Data: Dual Scaling and Its Application. University of Toronto Press, 1980. 276 p.

Transformation processes and the formation of anticorruption economic order in Ukraine: teach. manual Donetsk: DonNTU, 2009. - P. 126-130.

I. Вієбе, Sony Europe Limited (Штутгарт, Німеччина);

В. Д. Олійник, д.е.н., доцент, Сумський державний університет (Суми, Україна);

Ю. І. Галинська, к.е.н., доцент, Сумський державний університет (Суми, Україна).

Інноваційний інструмент управління колабораційним альянсом в системі "держава-регіон-підприємство" щодо вилучення рентних доходів у видобувній промисловості

Оцінено стан та перспективи трансформації рентної політики України і запропоновано рекомендації щодо 
вдосконалення рентних відносин через запровадження інноваційного інструментарію регулювання колабораційних відносин у галузі паливодобування. У роботі пропонується механізм взаємодії всіх учасників суспільства щодо фрормування та розподілу рентного доходу від видобування природних ресурсів через створення колабораційних альянсів між державою, видобувними підприємствами та регіонами. Проведені дослідження показали, що колабораційні альянси є найбільш прийнятною та перспективною організаційною формою, через яку можна узгодити інтереси всіх учасників формування та розподілу й перерозподілу рентного доходу. За допомогою анкетування та методу Дельфіз 2015 до 2017 року були проведен дослідження щодо можливості створення колабораиійного альянсу в системі «держава - регіон - підприємство», визначен недоліки та переваги для всіх учасників альянсів та виявлено соціо-еколого-економічні ризики при їх формуванні та функиіонуванні, що можуть гальмувати процес узгодження інтересів їх учасників. Ссформовано систему ризик-менеджменту при ффункціонуванні колабораційних альянсів, який включає підсистему ідентиффікаиії, вимірювання, супроводження (контролю та моніторингу ризиків). Визначено коефічієнт конкордації М. Кендалла і Б. Сміта під час оцінювання ймовірності настання негативних наслідків. Для формалізації виявлених ризиків при функціонуванні колабораційного альянсу розроблено науковометодичний підхід до ранжування соціальних, економічних та екологічних ризиків при створенні колабораційних альянсів за допомогою методу нечіткої логіки (Fuzzy Logic), що базується на врахуванні індикаторів стійкості колабораційних відносин під час визначення найбільш значущих ризиків та їх взаємозалежностей. Запропоновані шляхи мінімізації настання негативних ризиків при функиіонуванні колабораційних альянсів в системі «держава - регіон - підприємство» щодо розподілу природно-ресурсної ренти у галузі паливодобування. Дослідження довели, що сьогодні в умовах транссоормації рентної політики та соціально-економічних відносин державне управління повинне формувати соціальні цінності суспільства через екологічне використання й споживання ресурсів івпроваджувати заощадливу політику щодо видобування природних ресурсів України. При впровадженні колабораційного альянсу можуть бути враховані інтереси його сторін-учасників щодо перерозподілу рентних доходів від видобування природних ресурсів з врахуванням особистої та соціальної відповідальності при видобуванні природних ресурсів та охорони довкілля. При цьому правильно виявлені та оцінені ризики при фформуванні та функиіонуванні колабораційних альянсів в системі «держава - регіон - підприємство» допоможуть оцінити та оптимізувати розподіл природно-ресурсної ренти від видобутку природних ресурсів з ціллю компенсування та заощадження їх для майбутніх поколінь. Таким чином, можна зробити висновок, що колаборація держави і видобувних підприємств та місцевих громад не лише можлива, а й необхідна для ефекттивного фрункціонування еколого-економічної системи держави. При иьому паливодобувні підприємства можуть функціонувати в умовах коопетиції, створюючи додаткові стимули для розвитку підприємств, мінімізуючи ризики і генеруючи інноваційні ідеї.

Ключові слова: колабораційний альянс, рентний дохід, природні ресурси, економічні ризики, вилучення рентного доходу 